\title{
Razvoj sestrinstva u Karlovcu u razdoblju od osnutka grada do prve polovice 20. stoljeća
}

\section{The development of nursing in Karlovac in the period from the founding of the city to the first half of the $20^{\text {th }}$ century}

\author{
Snježana Mirilović, Blaženka Pavlić, Karolina Vižintin, Afrodita Gavrilidis \\ Opća bolnica Karlovac, A. Štampara 3, 47000 Karlovac, Hrvatska / General hospital Karlovac, A. Štampar 3, 47000 Karlovac, Croatia
}

\begin{abstract}
Sažetak
Uvod: Povijest skrbi za bolesne i potrebite u Karlovcu veže se za osnutak grada. Bolnice se grade isprva unutar tvrđave, a od 1779. godine i izvan tvrđave. Osoblje koje je radilo u bolnicama bili su priučeni liječnici koji su se s vremenom stručno osposobljavali. Njihova se imena navode u najranijim bolničkim spisima. Rad osoba koje su pomagale liječnicima i njegovale bolesnike oskudno je opisan i ne nalazimo podatke o tome tko su bile prve školovane medicinske sestre koje su radile u Karlovcu. Autorice su u radu pokušale učiniti rekonstrukciju početaka sestrinstva u Karlovcu i pronaći imena prvih sestara te podatke o školovanju i djelokrugu i/ili mjestu rada.
\end{abstract}

Metode: Polazište za izradu rada bili su dokumenti pohranjeni u pismohrani Opće bolnice Karlovac, arhivskim fondovima i zbirkama Hrvatskog državnog arhiva (HDA) te Državnom arhivu u Karlovcu (DAKA), kao i dokumenti pohranjeni u pismohrani Škole za medicinske sestre Mlinarska, Družbe sestara milosrdnica sv. Vinka Paulskog u Zagrebu, i Milosrdnih sestara sv. Križa u Đakovu. Kao dopuna ovim izvorima korišteni su do sada objavljeni radovi.

Rezultati: Pregledom pronađene povijesne građe saznajemo da se do 19. stoljeća ne nalaze imena ni zvanja osoba koje su njegovale bolesne. Postoje zapisi o imenima i prezimenima liječnika i bolesnika, ali za pomoćno se osoblje pretpostavlja da su to bile priučene žene. Kao prvi educirani kadar spominju se redovnice koje su krajem 19. stoljeća došle raditi u gradsku javnu bolnicu. Redovnice su radile i u sklopu Crvenog križa te priručnim bolnicama zajedno s građankama Karlovca. Na temelju uvida u arhivsku građu doznaju se imena sestara koje su djelovale u Karlovcu, kao i njihov djelokrug te mjesto rada. Osobe koje se najranije spominju u zapisima su primalje Ana Lamprecht i Sofija Piljuga, ali nisu pronađeni podaci o njihovoj izobrazbi. Na temelju pregledane povijesne građe može se izdvojiti Perpetua Kovačić koja je bila zaposlena u Karlovcu kao prva redovnica koja se školovala u Školi za sestre pomoćnice u Zagrebu.

Zaključak: Cjelokupan sestrinski rad u bolnicama u Karlovcu provodile su većinom redovnice. Brinule su o bolesnima, pripremale hranu, uređivale okoliš i provodile higijenu u bolnici. Rad je bio zahtjevan i popraćen teškim radnim uvjetima. Analizom povijesne građe doznaju se mnoga imena osoba koje su njegovale i skrbile o bolesnima u Karlovcu. Daljnjim istraživanjem i analizom povijesnog materijala moglo bi se doći do dodatnih i/ili novih informacija te drugačijih zaključaka. Ostaje nepoznat podatak o osobama koje su njegovale bolesnike u gradskoj javnoj bolnici u razdoblju od njezina osnutka do dolaska prvih redovnica.

Ključne riječi: povijest sestrinstva, Karlovac, Družba sestara milosrdnica sv. Vinka Paulskog, Milosrdne sestre sv. Križa

\begin{abstract}
Introduction: The history of care for the sick and people in need in Karlovac is linked to the founding of the city. Hospitals were first built inside the fortress, and from 1779 onwards outside the fortress. The staff working in the hospitals included trained doctors who, over time, got professionally educated. Their names are mentioned in the earliest records of hospitals. The work of the people who helped doctors and cared for the patients is poorly described and we do not find any information regarding the first educated nurses who worked in Karlovac. The authors of this paper tried to reconstruct the beginnings of nursing in Karlovac and find the names of the first nurses and information about their education, scope and/or place of work.
\end{abstract}

Methods: The starting point for this work were documents stored in the archives of the Karlovac General Hospital, archives and collections of the Croatian State Archives (HDA) and the State Archives in Karlovac (DAKA). We also used documents stored in the archives of the School of Nursing Mlinarska, Society of Sisters of Charity St. Vinko Paulski in Zagreb, and the Sisters of Mercy of St. Cross in Đakovo. In addition to these sources, previously published papers were also used.

Results: A review of the found historical material until the 19th century does not reveal the names or titles of the people who cared for the sick. There are records of the names and surnames of doctors and patients, but the support staff is presumed to have been hastily trained women. The nuns who came to work in the Town Public Hospital at the end of the 19th century are mentioned as the first educated staff. The nuns also worked as part of the Red Cross and handy hospitals together with the citizens of Karlovac. By reviewing the archives, the names of the sisters who worked in Karlovac, as well as their scope of work and place of work, are found. The people first mentioned in the records are midwives Ana Lamprecht and Sofia Piljuga, but there is no data on their education. Based on the reviewed historical material, Perpetua Kovačić was the first nun employed in Karlovac and educated in the School for Nurses in Zagreb.

Conclusion: The entire nursing work in the hospitals in Karlovac mostly did nuns. They cared for the sick, prepared food, arranged the environment, and carried out hygiene in the hospital. The work was demanding and accompanied by difficult working conditions. The analysis of the historical material reveals many names of people who cared for the sick in Karlovac. Further research and analysis of historical material might lead to additional or new information and possible different conclusions. The data on the people who cared for the patients in the Town Public Hospital in the period from its establishment until the arrival of the first nuns remains unknown.

Keywords: history of nursing, Karlovac, Society of Sisters of Charity of St. Vinko Paulski, Merciful Sisters of St. Križ 


\section{Uvod}

Povijest skrbi za bolesne i potrebite u Karlovcu veže se za osnutak grada. Usporedo s gradnjom tvrđave zbog obrane od turskih osvajanja, gradile su se i bolnice. U bolnicama su se zbrinjavali ranjenici, nemoćni i oboljeli od zaraznih bolesti. Zarazne bolesti bile su čest pratilac loših stambenih prilika, loših higijenskih uvjeta i primitivne vodoopskrbe. Širenju zaraznih bolesti pogodovao je i položaj grada uz granični koridor između Austro-ugarskog i Turskog Carstva. Bolesti koje bilježimo u tom razdoblju su: epidemije kuge, kolere, velikih boginja, pjegavca, dizenterije, tifusa i zarazne žutice [1].

Grad Karlovac osnovan je podno stare gradine Dubovac 1579. godine kao tvrđava radi zaštite od turskih osvajanja. Zbog svog geopolitičkog položaja, Karlovac je imao važnu funkciju u obrani Austro-ugarskog Carstva i cijele zapadne Europe od invazije Turaka. U tu svrhu, ugarsko-hrvatski kralj Rudolf II. povjerio je brigu o obrani grada austrijskom nadvojvodi Karlu II. Habsburškom. On je osnovao Gradačko ratno vijeće (Ratno vijeće u Grazu) kojem su bile podređene sve vojne i ratne službe. Osnovao je i Službu građevne granične komisije na čelu s Pappendorfom, glavnim vojnim inženjerom. Godine 1578. u Brucku na Muri, Gradačko ratno vijeće donijelo je odluku o gradnji nove moderne obrambene tvrđave na području Hrvatske. Gradnja je započela 13. srpnja 1579. godine što predstavlja i datum osnutka grada. Ime Karlstadt, Carolostadium ili Karlovac, grad je dobio po osnivaču, austrijskom nadvojvodi Karlu. Tvrđava je izgrađena u obliku šesterokrake zvijezde sa središnjim trgom i ulicama koje se sijeku pod pravim kutom. Na trgu je 1580. godine podignuta crkva Presvetog Trojstva. Unutar tvrđave gradile su se vojarne, oružane, barutane, spremišta, vojne bolnice, vojna ljekarna („K crnom orlu”, 1726.) i stambene kuće. Prema katastarskim zapisima iz 1770. godine bila su evidentirana 252 vlasnika gradskih kuća. Oko tvrđave izgrađeni su bedemi i šančevi koji su grad štitili ne samo od turskih napada nego i poplava [1, 2, 3].

Od 1579. do 1781. godine, kada je Karlovac proglašen slobodnim kraljevskim gradom, tvrđava je imala prednost pred gradom, a vojska i njezine institucije pred građanima i gradskom upravom. Ipak, odlukom kralja Rudolfa II. grad i građani dobili su mogućnost razvoja trgovine. Stoga su najvažnije mjesto u gradu, uz vojsku, imali mnogi obrtnici koji su se udružili u cehove i tako počeli jačati građansku strukturu društva [3].

Broj stanovnika unutar tvrđave povećavao se i pojavio se nedostatak prostora za stanovanje. Osim turskih napada, grad su uništavale poplave, požari i potresi što je dovodilo do sve težih životnih uvjeta. Sve je to doprinosilo iseljavanju građana izvan tvrđave. Početkom 17. stoljeća počelo je naseljavanje u prigradskim mjestima koja počinju formirati „pograđe" [4].

Tijekom 18. i 19. stoljeća, ponajviše zahvaljujući procvatu trgovine i lađarstva Kupom, Karlovac je bio jedan od najbogatijih i najrazvijenijih hrvatskih gradova. O tome svjedoči i podatak da su 1805. godine upravo Karlovčani plaćali najveći porez u Hrvatskoj. Uspješan gospodarski razvoj, gradnja prometnica, demografski rast i procvat kulturnog života svrstavali su Karlovac u jedan od najznačajnijih gradova u Hrvatskoj. Od početka 20. stoljeća pa sve do danas Karlovac je civilni, upravno-trgovački i kulturni centar svoje regije $[3,4]$.

Bolnice se grade isprva unutar tvrđave, a od 1779. godine i izvan tvrđave. Osoblje koje je radilo u bolnicama bili su priučeni liječnici koji su se s vremenom stručno osposobljavali. Njihova se imena navode u najranijim bolničkim spisima. Rad osoba koje su pomagale liječnicima i njegovale bolesnike oskudno je opisan i ne nalazimo podatke tko su bile prve školovane sestre koje su radile u Karlovcu. Stoga se u radu pokušala napraviti rekonstrukcija početaka sestrinstva u Karlovcu i pronaći imena prvih sestara te podatke o školovanju i djelokrugu i/ili mjestu rada.

Polazište za izradu rada bili su dokumenti pohranjeni u pismohrani Opće bolnice Karlovac, arhivskim fondovima i zbirkama Hrvatskog državnog arhiva (HDA) i Državnom arhivu u Karlovcu (DAKA), kao i dokumenti pohranjeni u pismohrani Škole za medicinske sestre Mlinarska, Družbe sestara milosrdnica sv. Vinka Paulskog u Zagrebu, i Milosrdnih sestara sv. Križa u Đakovu. Kao dopuna ovim izvorima korišteni su do sada objavljeni radovi.

\section{Izgradnja te rad bolnica i ubožnica u Karlovcu}

\section{Vojne bolnice unutar tvrđave}

Zbog intenzivnih ratnih djelovanja protiv Turaka, javlja se potreba za liječnicima - ranarnicima, ali i za izgradnjom bolnice. U razdoblju od 1580. do 1583. godine izgrađena je prva karlovačka vojna bolnica unutar tvrđave. Bolnicom je upravljao pukovnijski liječnik, a podaci o njezinu izgledu i funkcioniranju vrlo su oskudni. Zbog ratnih događanja, vremenskih nepogoda i lošeg građevnog materijala, tvrđava se često urušavala i zahtijevala obnavljanje. Stara je bolnica zbog dotrajalosti bila srušena [1]. Nova vojna bolnica koja se i danas nalazi u staroj jezgri grada - "Zvijezdi" izgrađena je 1758. godine (Slika 1.). Trenutno se planira obnova zgrade i prenamjena u studenski dom.

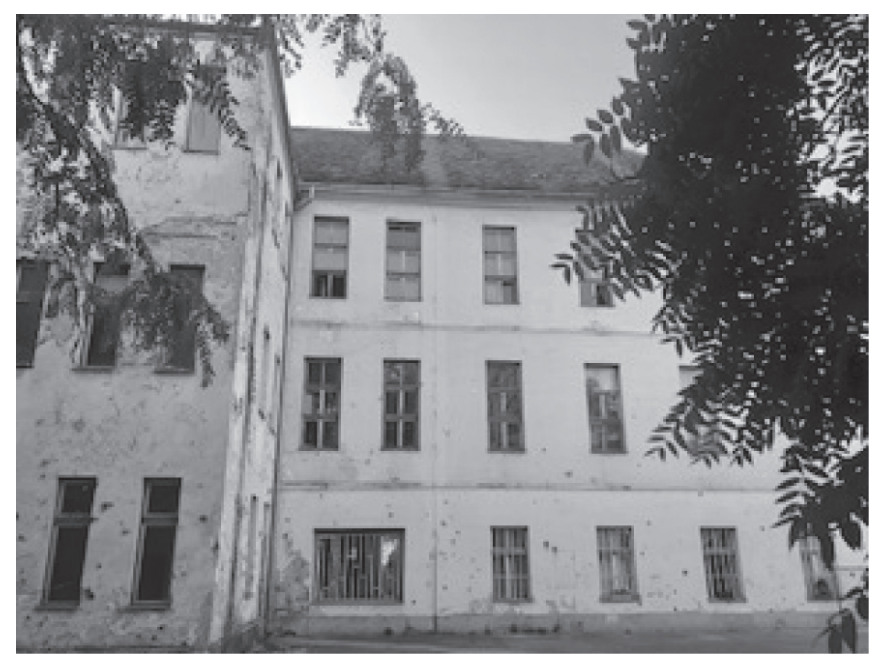

SLIKA 1. Stara vojna bolnica u tvrđavi sagrađena 1758. godine. Izvor: privatno photo: Snježana Mirilović 
Godine 1783. godine izgrađena je vojna bolnica s 200 kreveta. U bolnici su se liječili i građani koji su bili nastanjeni unutar i u okolici tvrđave. Spominju se prvi liječnici koji su radili u bolnici: Spazek, Inami i Kasun [3]. Podaci o ostalom osoblju nisu pronađeni.

Od 1770-ih godina razvojem trgovine i obrta, Karlovac postaje važno tranzitno središte i posrednik međunarodne trgovine prema moru. Istovremeno je došlo do raslojavanja društva pa će se tako bogatiji stanovnici liječiti i umirati u svojim kućama, a siromašni i beskućnici najčešće ostaju na ulicama. Najsiromašniji slojevi pučanstva smještali su se u franjevački samostan gdje su im vojni liječnici i kapelani pružali medicinsku pomoć te osiguravali besplatne obroke [2].

Franjevci koji su došli u tvrđavu 1657. godine bili su vojni kapelani. Brinuli su o siromašnom stanovništvu, bolesnima i beskućnicima. Godinu dana kasnije preuzeli su Župu, crkvu Presvetog Trojstva, i dušobrižništvo nad vjernicima u tvrđavi. Bilo im je povjereno vođenje karlovačkih škola do 1820. godine, kada upravu nad školama preuzima grad Karlovac. U jednoj od vojarni otvorili su i Pučku dječačku školu, prvu u Karlovcu, vjerojatno u razdoblju od 1670. do 1680. godine [4]. Franjevci su u svom samostanu imali ljekarnu sve do 1763. godine, kada je dekretom carica Marija Terezija zabranila rad svim redovničkim ljekarnama [5].

Zbog klimatskih i topografskih prilika, velike vlažnosti i čestih poplava rijeka u blizini grada, pojavljivale su se i zarazne bolesti. Najznačajnije su bile kuga, kolera, tifus, malarija, pjegavac te velike boginje. Bolnica je s vremenom postala nedostatna za adekvatno pružanje skrbi cjelokupnom stanovništvu te se nameće potreba za izgradnjom gradske javne bolnice [1].

\section{Izgradnja bolnice i ubožnice „Purgerski špital" na Dubovcu}

Odlukom karlovačkog magistrata', 1779. godine počela je izgradnja bolnice i ubožnice „Purgerski špital” na Dubovcu, na mjestu današnjeg rimokatoličkog gradskog groblja. U aktima gradskog magistrata doznaje se pučki naziv bolnice iz oporuke jedne građanke. U svojoj oporuci od 3. siječnja 1806. godine građanka Ana Cuculić donira 4 rajska forinta za bolnicu „Purgerski špital”. U službenim spisima bolnicu nazivaju lat. Xenodochium et nosocomium; njem. Armen und Krankenhaus, odnosno ubožnica i bolnica. [6]

U prizemlju bolnice nalazile su se bolesničke sobe, soba za „Bettrichter"2, kuhinja i velika kapela.

Na katu bolnice nalazila se soba za „partaje“3. U sklopu bolnice bila je i ljekarna. U bolnici se uglavnom liječila sirotinja koja nije imala novca za liječenje kod kuće pa je bolnica više imala status ubožnice nego bolnice. O bolesnima su brinuli kirurzi i jedna primalja. Prema zapisu iz 1806. godine tzv. Lista nationalismorum 1806 koji je predstavljao godišnju ocjenu zaposlenika, a kojom gradski fizik potvrđuje da su svih

\footnotetext{
${ }^{1}$ Gradska skupština, poglavarstvo

2 Doslovan prijevod: 'ona koja namješta krevete, odnosno bolničarka'.

${ }^{3}$ Doslovan prijevod: 'stanar, stranka, partija, odnosno bolesnici'. Vidi u: Klaić B. Rječnik stranih riječi. Zagreb: Zora; 1966.
}

5 kirurga i jedna primalja Ana Lamprecht dobrog zdravlja, marljivi i ćudoredni [6].

Ana Lamprecht bila je majka Rudolfa Lamprechta (1781. - 1860.) magister obstetriciae et chirurgiae koji je u Bolnici milosrdne braće u Zagrebu 1812. godine otvorio tečaj za magistre kirurgije. Upisalo se deset pristupnika, a trajao je samo jedan semestar te je zatim ukinut nakon čega Lamprecht svoju karijeru nastavlja u Padovi [7].

$\mathrm{U}$ to vrijeme kirurzi nisu bili fakultetski obrazovani, nego su pohađali kirurške tečajeve [2].

U izvještaju koji je bio podnesen gradskom magistratu 1806. godine navodi se da je u bolnici i ubožnici „Purgerski špital" skrb i briga o bolesnicima na visokoj razini. Već 1817. godine socijalna i građevinska komisija magistrata utvrđuje da je bolnica u vrlo lošem stanju, da brzo propada i da joj prijeti opasnost od urušavanja. Bolnica je srušena 1870. godine, a na njezinu je mjestu izgrađen dio kapelice Svih svetih koja postoji još i danas [1].

\section{Izgradnja gradske javne bolnice 1846. godine}

Na udaljenosti od jednog kilometra od stare bolnice, na Dubovcu uz Lujzinsku cestu, počinje se graditi nova Gradska javna bolnica i ubožnica donacijom karlovačkog dobrotvora Nikole Šebetića. On je oporučno sav svoj imetak i zemlju darovao za izgradnju ubožnice i Gradske javne bolnice uz uvjet da svi članovi njegove obitelji imaju doživotno besplatno liječenje. Brigu o imetku povjerio je upravi Karlovačke čitaonice čiji su članovi bili neki od najuglednijih ljudi ne samo iz Karlovca nego i iz cijele Hrvatske. Članovi čitaonice brinuli su o izgradnji bolnice, ali i o siromašnima i nemoćnima pa je iz Šebetićeve zaklade plaćala liječenje potrebitima [1].

Uz dodatne donacije brojnih uvaženih Karlovčana, 1846. godine izgrađena je Gradska javna bolnica i kupljen namještaj. Bila je to jednokatnica sa 60 kreveta za bolesnike i 20 kreveta za ubogare. Drugi kat bolnice nadograđen je 1884. godine, a kasnije i paviljon za zarazne bolesti te mrtvačnica. U bolnici su radili jedan primarni i jedan sekundarni liječnik. Sekundarni liječnik bio je drugi liječnik u bolnici, pomoćnik i zamjenik primarnog ili glavnog liječnika. Podvorbu i njegu bolesnika, pripremu hrane i druge pomoćne poslove obavljalo je sedam redovnica iz Družbe sestara milosrdnica sv. Vinka Paulskog, a za ostalu službu sedam sestara, četiri sluge i jedan stolar $[1,8]$.

Pregledom bolesničkih kartona i izvješća u razdoblju od 1886. godine do početka Drugog svjetskog rata ne mogu se utvrditi imena osoba koje su brinule za bolesnike ni koliko se njih i na koji način školovalo.

Iz zapisnika gradskog magistrata spominju se samo gradske ubogarke Matilda Majer i Magda Pavković koje su 1925. godine tražile cipele da bi mogle raditi u Gradskoj ubožnici [9].

Možemo pretpostaviti da je to kadar koji je regrutiran na način na koji to opisuje liječnik Žiga Švarc u svojim sjećanjima na uvjete rada i teškoće s kojima se susretao u radu s pomoćnim osobljem (neizobražene pomoćne sile) prije osnivanja Škole za sestre pomoćnice: „...U našim bolnicama vršile su službu opatice, koje su tek praktički jedna od druge 
naučile taj posao ili su u nekojim bolnicama taj posao vršile sasvim neupućene žene iz najnižih socijalnih slojeva jer je zvanje bolničarke bilo na zlu glasu, kao teško i slabo plaćeno zvanje. Obično su otpuštene bolesnice, koje bi ostale bez zarade i koje poradi pomanjkanja svake kvalifikacije nisu imale ni nade, da će zaposlenje naći, preuzele njegu bolesnika. Njihov položaj bijaše što više ispod onoga, što su ga u kućanstvu zauzimale sluškinje... „[10].

U kotarskim ${ }^{4}$ zapisima spominju se samo babice (primalje) koje su porađale i brinule o rodiljama.

Otprilike od 1846. do 1925. godine žene su rađale u kući uz asistenciju gradskih ili privatnih primalja, a samo patološke porode obavljali su liječnici educirani za operativne zahvate. $U$ bolnice su primane siromašne, neudate žene, kućne pomoćnice ili žene $s$ patološkim trudnoćama u umirućoj fazi. Jedino ime koje nalazimo u izvorima je Piljuga Sofija ${ }^{5}$, primalja koja je radila na području Udbine i Rakovca. Živjela je od 1871. do 1910. godine u Karlovcu [1, 3].

\section{Djelovanje redovnica u karlovačkim bolnicama}

Glavni gradski liječnik i fizik Milan Nemičić 1886. godine potpisuje Ugovor s Družbom sestara milosrdnica sv. Vinka Paulskog koje preuzimaju njegovanje bolesnika i brigu o cjelokupnom radu bolnice [1].

Dok se Gradska javna bolnica gradila, i dalje je bilo potrebno zbrinjavati bolesne pa su se u vojarnama i školama improvizirale bolnice. Pomoć u donacijama, hrani i njezi ranjenih i bolesnih pružale su priučene građanke samostalno ili putem djelovanja u Crvenom križu.

Građanke koje se spominju kao bolničarke krajem 1914. godine radile su u priručnoj bolnici koju je osnovao Crveni križ. Navode se gđica Marjanović, gđa D. Marjanović, gđica Slavica Kučera, gđa Oršanić, gospodin Gjuro Tarnik, gđa Dragica Prebit-Lukšić i gđica Slavica Rossi. U zapisima nalazimo i imena dvaju liječnika, dr. Gostla i dr. Hermana [2].

U priručnoj bolnici Crvenog križa radile su Milosrdne sestre sv. Križa. U zapisima nalazimo da je 3. srpnja 1918. godine telegrafski zatraženo od provincijalne poglavarice Majke Engelberte Sporčić da časne sestre Efrema Turba, Kalista Reichnach, Konrada Karabaia, Dorotea Jakupčić preuzmu dvorbu bolesnika u bolnici u Karlovcu. Sestre su se iz Karlovca vratile 3. lipnja 1919. godine. Podaci o tome tko je tražio njihovu pomoć u Karlovcu i gdje su se navedenog datuma vratile nisu pronađeni [11].

\footnotetext{
${ }^{4}$ Kotari - teritorijalno-upravne i političke jedinice koje je 1785. godine uveo car i kralj Josip II. u Hrvatsku. Nazivi i područja koja su obuhvaćala mijenjala su se tijekom povijesnih razdoblja. Kotari su ukinuti 1967. godine kada su ustrojene općine koje su podijeljene na mjesne zajednice. Kotari su se tada dijelili na upravne općine. Karlovački kotar obuhvaćao je upravne općine Draganić, Duga Resa, Jaškovo, Novigrad na Kupi, Ribnik, Ozalj, Netretić. Vidi u: Karlovački leksikon (2008), str. 329.

5 Početkom 20. stoljeća objavljivala je literarne radove u karlovačkim glasilima Svjetlo, Glasonoša i Srbobran. Najistaknutiji joj je autobiografski rad "Majčine suze" u kojem opisuje tugu za izgubljenim sinovima. Pisala je i pripovijetke s motivima iz svakodnevnog života. Više o književnom stvaralaštvu Sofije Piljuge u: Vrga B. Majčine suze. Prosvjeta. 2015: maj 125:57-8; Karlovački leksikon (2008.) str. 455.
}

Redovnice iz Družbe sestara milosrdnica sv. Vinka Paulskog djelovale su u gradskoj bolnici u Karlovcu od 1888. do 1978. godine. Prve redovnice došle su 1. travnja 1888. godine. Starješica je bila sestra Kerubina Selan. Sestre su imale besplatan stan i hranu te su dobivale 20 forinti godišnje za odjeću i obuću. U sklopu bolnice imale su malu kapelicu. [12] Iz matičnih knjiga doznaju se neka imena i razdoblja u kojima su djelovale. To su redovnice: Parmena Lesar (1911. 1940.), Oceana Predikaka (1920. - 1926.), Dominatora Bratković (1926. - 1932.), Patagata Vadnov (1932. - 1934.), Leonida Čebrajec (1942. - 1945.), Jolanka Majer (1944. - 1962.), Perpetua Kovačić (1945. - 1949.) i Leokadija Turkalj (1946. - 1953.) [13].

Kovačić Katarina s. Perpetua rođena je 1. listopada 1891. godine u Mariji Bistrici. U Družbu sestara milosrdnica sv. Vinka Paulskog u Zagrebu dolazi 12. listopada 1908. godine, a dvije i pol godine kasnije prima prve zavjete [14]. Školu za sestre pomoćnice u Zagrebu upisuje 1923. te diplomu sestre bolničarke dobiva 18. ožujka 1925. godine [15]. Treba napomenuti da se termin sestra bolničarka u tadašnjem kontekstu ne koristi u smislu pomoćnog zdravstvenog osoblja, već kao smjer koji obrazuje sestre za rad u bolnici [16]. Službu u svojstvu bolničarke započinje 1915. godine u bolnici u Petrinji, zatim odlazi u bolnicu u Sarajevo gdje ostaje do 1923. godine. Po završetku školovanja postaje starješica te $\mathrm{u}$ tom svojstvu nadalje radi u bolnicama i sanatorijima. Od 1926. do 1932. godine ponovno radi u bolnici u Petrinji. Od 1932. do 1936. godine radi u sanatoriju u Beogradu. U sanatoriju i u Domobranskoj bolnici u Osijeku radi od 1936. do 1942. godine. U gradskoj javnoj bolnici u Karlovcu radila je od 19. rujna 1945. do 22. kolovoza 1949. godine te se prema analizi dostupne građe može smatrati prvom školovanom sestrom redovnicom u Karlovcu. Od 1949. do 1971. godine, uz povremene prekide, radi u bolnici u Petrovaradinu. Vraća se u samostan gdje obavlja kućanske poslove do umirovljenja, 1. travnja 1974. godine. Preminula je 13. rujna 1976. godine u Zagrebu [14].

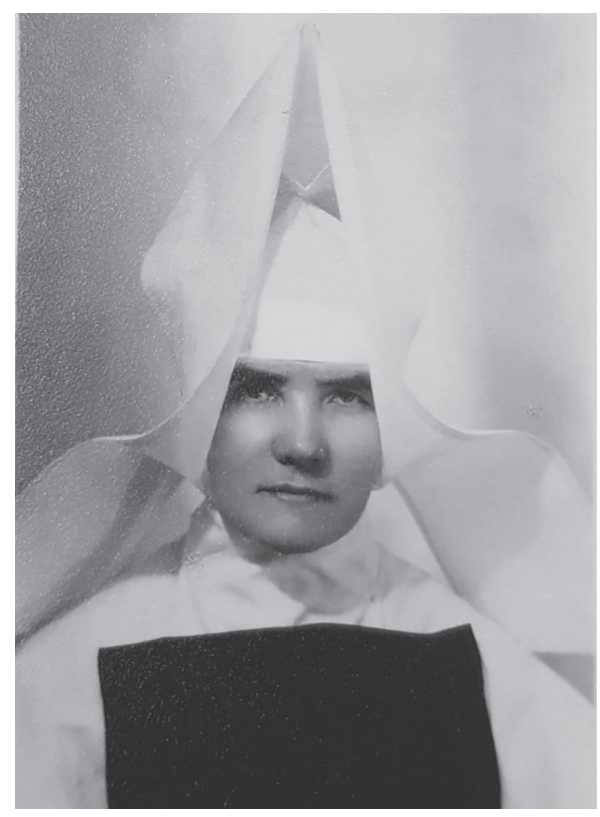

SLIKA 2. Perpetua Kovačić, vjerojatno 1911. Izvor: Arhiv Družbe sestara milosrdnica sv. Vinka Paulskog, Zagreb. 
Leokadija Turkalj radila je kao instrumentarka u Općoj bolnici, a Jolanka Majer na zaraznom odjelu. Leoncija Jaklanac i Leopoldina Goertner radile su na Otorinolaringologiji, Amanta Kordić i Gaudioza Novosel na Internom odjelu, Gaudencija Brčić na Internom odjelu i Otorinolaringologiji, Davorka Kordić i Urzicija Štrucelj na Kirurgiji, Julinka Tašić na Kirurgiji i Odjelu za tuberkulozu, a sestre Mara Gričar i Marijana Jurišić na Odjelu za tuberkulozu. Sestra Sperata Katić radila je u kuhinji, Armentarija Brecelj u ljekarni, Arbona Stanić brinula je o voćnjaku, a Nortburga Flis bila je zadužena za podjelu terapije u bolnici svim bolesnicima [1].

Flis Rozalija s. Notburga (Nortburga) rođena je 1. rujna 1894. godine u Jalkovcu, općina Varaždin. U Družbu sestara milosrdnica sv. Vinka Paulskog u Zagrebu dolazi 26. lipnja 1913. godine, a dvije godine kasnije prima prve zavjete. Radila je u svojstvu bolničarke i prije formalnog obrazovanja u Splitu i Dubrovniku. U karlovačkoj Gradskoj javnoj bolnici radila je kao bolničarka od 1927. do 1930. godine kada je premještena u bolnicu u Zagreb [17].

Za Notburgu Flis nalazimo dva različita podatka o njezinu školovanju. U matičnoj knjizi Škole za sestre pomoćnice u Zagrebu piše da je upisana u školu 1927. godine, ali se nakon mjesec dana ispisala iz škole. Smjer za bolničarku u istoj je školi upisala 1. rujna 1930., a završila ga je 2. srpnja 1931. godine [15]. U neslužbenom popisu koji se nalazi u Hrvatskom državnom arhivu zapisano je da je školu završila 1933. godine [18].

U Karlovcu ponovno radi od 15. srpnja 1931. do 27. veljače 1949. godine. Nakon toga odlazi raditi u bolnicu u Petrovaradinu. Umirovljena je 15. listopada 1972 . godine kada radi kao noćna čuvarica u kućnoj bolnici u samostanu. Preminula je 9. siječnja 1977. godine u Zagrebu [17].

Redovnice su radile u Gradskoj javnoj bolnici sve do kraja Drugog svjetskog rata [1]. U poslijeratno vrijeme mnoge su bile prisiljene napustiti službu jer nisu željele raditi u civilnom odijelu ili su bile izložene pritiscima i preseljenjima $u$ ustanove koje će im dopuštati rad [19].

\section{Zaključak}

Od osnutka Karlovca pa do kraja Drugog svjetskog rata bilo je vrlo malo obrazovanog kadra za njegu bolesnika pa su taj posao radile priučene osobe i redovnice koje su pohađale kratke tečajeve. Osnivanjem Škole za sestre pomoćnice 1921. godine u Zagrebu, školu upisuju i redovnice i civilne učenice pa od tada možemo govoriti o prvom obrazovanom kadru koji skrbi o bolesnima.

Cjelokupan sestrinski rad u bolnicama u Karlovcu provodile su većinom redovnice. Brinule su o bolesnima, pripremale hranu, uređivale okoliš i provodile higijenu u bolnici. Rad je bio zahtjevan i popraćen teškim radnim uvjetima. Analizom

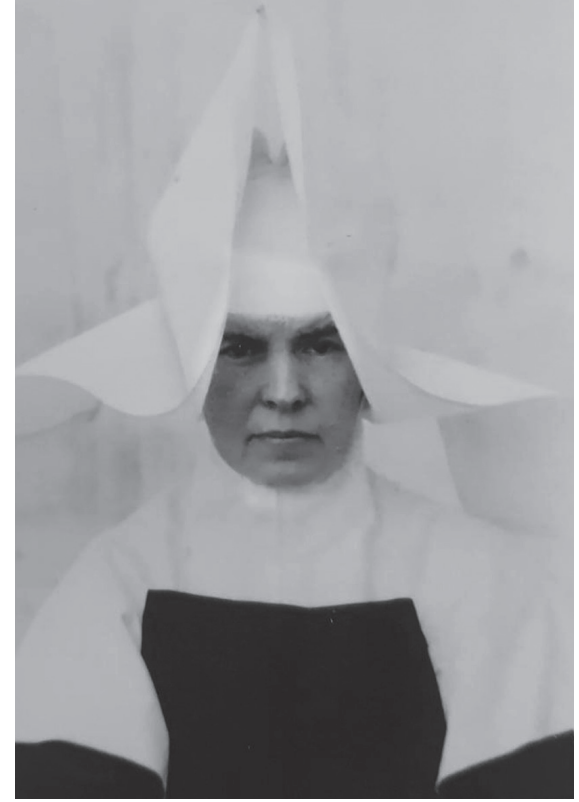

SLIKA 3. Notburga Flis, vjerojatno 1915. Izvor: Arhiv Družbe sestara milosrdnica sv. Vinka Paulskog, Zagreb.

dostupne povijesne građe doznaju se imena osoba koje su njegovale i skrbile o bolesnima u Karlovcu. Osobe koje se najranije spominju u zapisima su primalje Ana Lamprecht i Sofija Piljuga, ali nisu pronađeni podaci o njihovoj izobrazbi. Na temelju dostupne povijesne građe može se izdvojiti sestra Perpetua Kovačić kao prva školovana redovnica u Karlovcu. Daljnjim istraživanjem i analizom povijesnog materijala moglo bi se doći do dodatnih i/ili novih informacija te drugačijih zaključaka. Ostaje nepoznat podatak o osobama koje su njegovale bolesnike u Gradskoj javnoj bolnici u razdoblju od njezina osnutka do dolaska prvih redovnica.

\section{Zahvala}

Autorice zahvaljuju sestri Esteri Radičević iz Družbe Milosrdnih sestara sv. Križa iz Đakova i sestri Stjepanki Pavić iz Družbe sestara milosrdnica sv. Vinka Paulskog na dobivenim informacijama iz pismohrana družbi. Također zahvaljuju i gospodinu Mariju Dudasu na pomoći prilikom pregleda gradiva pohranjenog u Arhivu Opće bolnice Karlovac. Zahvaljujemo Sandi Franković, prof. za pomoć u prikupljanju gradiva pohranjenog u Hrvatskom državnom arhivu i savjetima prilikom pisanja rada.

\section{Nema sukoba interesa}

\section{Authors declare no conflict of interest}




\section{Literatura}

[1] Pavan G. 160 godina Opće bolnice Karlovac. Karlovac: Opća bolnica Karlovac; 2006.

[2] Peršin V, Rožman B, Holjevac B. Nastanak i razvoj crvenog križa u Karlovcu. Karlovac: Hrvatski crveni križ i gradsko društvo Crvenog križa Karlovac; 2006.

[3] Alegro A, Begedin D, Bogner-Šaban A, Bojkić V. i sur. Karlovački leksikon. Zagreb: Školska knjiga; 2008.

[4] Karlovac 13.7.1979. Analitičke studije karlovačke „Zvijezde”.1979. [internet] [pristupljeno 20. 9. 2021.] Dostupno na:

https://www.karlovac.hr/UserDocsImages//2016/ZVIJEZDA//KARLOVAC_13-07-1979.pdf

[5] Tartalja H. Razvoj ljekarništva u Karlovcu. u: Zatezalo Đ, Majetić T, Miholović K. Karlovac 1579. - 1979. Karlovac: Historijski arhiv u Karlovcu; 1979; 503-7.

[6] Morsan B. O karlovačkim bolnicama i doktorima. u: Zatezalo Đ, Majetić T, Miholović K. Karlovac 1579. - 1979. Karlovac: Historijski arhiv u Karlovcu; 1979; 491-502.

[7] Habek D. Povijest medicine uz razvoj primaljstva, porodništva i ginekologije. Zagreb; Medicinska naklada: 2015.

[8] Strohal R. Grad Karlovac opisan i orisan. Karlovac: M. Fogine; 1906.

[9] HR-DAKA-3 Poglavarstvo grada Karlovca 1918. - 1941. Skupštinski zapisnici 1924. godine, knjiga 1

[10] Švarc Ž. Nekoliko misli o sestrinskom zvanju i zaštiti djece. Sestrinska riječ. 1933; 1 (3-4): 31-7.
[11] Arhiv provincijalne kuće u Đakovu. Uredski dnevnik (Tagebuch). 1868. - 1945

[12] Družba sestre milosrdnice sv. Vinka Paulskog. Kratka povijest Družbe sestara milosrdnica sv. Vinka Paulskog u Zagrebu 1845. - 1922. Zagreb, 1935.

[13] Arhiv Družbe sestara milosrdnica sv. Vinka Paulskog u Zagrebu. Upisna knjiga I. dio. 1845. - 1933.

[14] Arhiv Družbe sestara milosrdnica sv. Vinka Paulskog u Zagrebu. Kovačić Katarina s. Perpetua 1911. - 1976. br. 2107

[15] Pismohrana Škole za medicinske sestre Mlinarska. Podaci preuzeti iz matične knjige učenica Državne škole za sestre pomoćnice

[16] Hofgräff D, Franković S. Osnutak Škole za sestre pomoćnice u Zagrebu 1921. - 1922. Arh. vjesn. 2017; 60: 165-84.

[17] Arhiv Družbe sestara milosrdnica sv. Vinka Paulskog u Zagrebu. Osobnik Flis Rozalija s. Notburga 1915. - 1977. br. 2435

[18] HR-DAZG-755 Društvo diplomiranih sestara pomoćnica, Popis svršenih sestara u Državnoj školi za sestre pomoćnice 1922. - 1937. sig 14 (kutija 61)

[19] Popić M. Odnos jugoslavenskog komunističkog režima prema Družbi sestara milosrdnica Svetog Vinka Paulskog - Zagreb od 1945. do 1952. godine. Disertacija. Sveučilište u Zagrebu, Hrvatski studiji. 2016. 